\title{
A KISGYERMEKES NŐK FOGLALKOZTATÁSI HELYZETE ÉS LEHETŐSÉGEIK
}

Az elmúlt években bár növekszik hazánkban a nők munkaerő-piaci szerepe, de a nők foglalkoztatási rátája tartósan alacsonyabb a férfiakénál és alacsonyabb a női EU-átlagnál is. Ezt nagyrészt az okozza, hogy hazánkban a kisgyermekes nők nem vagy nagyon nehezen tudnak visszatérni a munka világába, még akkor is, ha számos család- és foglalkoztatáspolitikai eszközzel segíti őket a kormányzat és a munkáltatók a munkaerő-piaci reintegrációban. A kisgyermekes anyák elhelyezkedési esélyei jelentősen nem javulnak, ha egy nő több gyermeket vállal, ez sok esetben a saját munkaerő-piaci kirekesztődéséhez vezet. Minél több gyermek van a családban, az anya foglalkoztatási rátája annál alacsonyabb. Hogyan lehet ezen javítani, milyen lehetőségek vannak az esélyhátrányok csökkentésére? Ezt vizsgálják a szerzők beavatkozó módszerrel, fókuszcsoportos vizsgálattal kisgyermekes szülők és HR-szakemberek bevonásával. Kutatási kérdésként az alábbit fogalmazták meg: Hogyan ítélik meg a kisgyermekes anyák saját munkaerő-piaci visszatérésüket és lehetőségeiket?

Kulcsszavak: kisgyermekes anyák, diszkrimináció, munkaerőpiac

A nők helyzetével számtalan hazai és nemzetközi kutatás foglalkozik (Fodor - Vicsek, 2006; Kispéter, 2012; Koncz, 1993; Koncz, 1996; Koncz,1999; Nagy, 1997; Nagy, 1999; Nagy, 2001; Nagy, 2005; Nagy - Fodor, 2015; Nagy - Primecz, 2010; Primecz et al., 2014). A leggyakoribb vizsgálati területek mégis a nők munkaerő-piaci helyzete, az esélyegyenlőség megvalósulása, a munka és a család öszszeegyeztethetősége, a munka és magánélet egyensúlya, a női és férfi felső vezetők eltérő attitűdjei. A kisgyermekes nők gyes-ről való visszatérésének lehetőségeivel és a munkaadók által alkalmazott hátrányos megkülönböztetéssel kevesebb tanulmány foglalkozik, ez motiválta cikkünk megszületését. A fogyó és elöregedő demográfiai háttérrel rendelkező európai országokban a nők egyre később vállalják az első gyermeküket (EU-28 átlagértéke 30 éves életkor), amely magyarázható a karrier iránti vággyal, vagy a megfelelő anyagi háttér megteremtésének igényével. Tovább nehezíti a gyermekvállalási döntést a munka és a magánélet összeegyeztethetőségének kérdése is. A nők nagyarányú inaktivitása főként a szülöképes korosztályban és az idősebbek között jellemző és mindkét esetben nemspecifikus tényezőkre vezethető vissza (Vajda, 2014). Magyarország számára, ahol a nők foglalkoztatási rátája európai viszonylatban alacsony, kiemelt jelentőségű a kisgyermekes nők magas inaktivitásának a csökkentése, a minél gyorsabb munkaerő-piaci visszavezetés.

A nők munkaerő-piaci helyzete jelentősen eltér a férfiakétól (bérkülönbségek, a nőkre háruló kettős teher, valamint a munka és a magánélet összeegyeztethetősége). A nők és a férfiak közötti keresetkülönbséget és foglalkoztatásbeli eltéréseket a neoklasszikus közgazdasági elmélet azzal magyarázta, hogy a nők életük során többször is elhagyják a munkahelyüket, így rövidebb idő áll rendelkezésükre, hogy az emberi tőkébe történő befektetésből származó hasznot megszerezzék (England, 1992). Ezt Koncz (2011, p. 89.) is megerősíti, hogy ,,a neoklasszikusok szerint a munkaerő-piaci szereplők és a családok racionálisan döntenek, a munkaerőpiac hatékonyan müködik."
A női munkaképesség elméletének kidolgozása Elisabeth Beck-Gernsheim és Ilona Ostner nevéhez kapcsolódik, akik a keresőtevékenység és a házimunka közötti különbségeket fogalmazták meg. A házimunka esetében nincs éles határvonal a szabadidő és a munkaidő között, mint ahogy az otthon és a munkahely is térbelileg egybeesik. A kutatónők szerint a keresőtevékenység teljes embert követel meg, erre pedig a férfiak a legalkalmasabbak, mivel nekik nem kell a háztartással is foglalkozniuk. A munkaerőpiacon jelenlévő aktívan kereső nők ezért vannak kitéve a kettős tehernek. Azonos munkakörökben a nők hátrányos helyzetét az eltérő érdekek érvényesítéséből származtatják, és nem foglalkoznak a munkaadói diszkriminációval sem (Beck-Gernsheim, 1979; Ostner, 1990). A hierarchiaelmélet a nemek közötti eltérést és a nemek közötti hierarchia fogalmait elválasztja egymástól. A kutatások során arra jöttek rá, hogy nem a munka tartalmának, hanem a vele járó társadalmi státusának van nagy befolyása arra, hogy azt a nők vagy a férfiak végzik-e (Belinszki, 1997). Azaz a nők nem azért végeznek több háztartási munkát, mert lenne valamilyen nem-specifikus képességük ennek hatékonyabb elvégzésére, hanem mert a társadalmi hierarchiában alacsonyabb szinten vannak, így a háztartási munkák nagy része rájuk hárul.

Gardiner (1975) arra hívta fel a figyelmet, hogy a nők háztartási munkája nélkülözhetetlen a kapitalista rend működése szempontjából, mégis elsősorban a férfiakat tehermentesítik. „A szocialista termelési rendszerben nem kérdőjeleződött meg a 'férfiasság társadalmi normája'. Ez a férfiak számára a reproduktív szférában végzendő tevékenységektől való mentességet és a fő kenyérkereső szerepet jelentette" (Asztalos-Morell, 1997, p. 45.). A rendszerváltás előtti Magyarországon a teljes foglalkoztatás volt jellemző, majd a szocialista rendszer felbomlása után a gazdasági szerkezetátalakulás következtében a nők tartósan vagy véglegesen kiszorultak a munkaerőpiacról (Köllö - Nagy, 1995). A nők és férfiak eltérö munkaerö-piaci esélyeit a nők aránytalan otthoni szerepvállalását rögzítő 
társadalmi normák, az eltérö otthoni munkamegosztás és a munkáltatóknak a dolgozókkal szemben támasztott, azok nemétől függő elvárásai határozzák meg (Krizsán et al., 2009).

A gyermekgondozási segély (gyes) egészen 1967 óta a magyar családtámogatási rendszer központi eleme, melyet lényegében minden kisgyermeket nevelő anyának folyósítanak hosszabb-rövidebb ideig. A gyes bevezetésével a nők kettős tehervállalása, a kereső munkavállalás és a családi gondoskodás kettős terhe vált normaadóvá, a gyes a dolgozó nőt tette kedvezményezetté. A demográfiai okok mellett munkaerö-piaci megfontolásokat is feltételezhetünk a gyes bevezetése mögött. A gyes és a munkaerő-piaci visszatérés kapcsolatát többen is kutatták már. Közgazdasági elemzésekre alapozva Scharle (2007) felhívta arra a figyelmet, hogy a magyar pénzbeli gyermeknevelési támogatások erős ellenösztönzőt jelentenek a nők munkaerő-piaci (re)integrációjával szemben. Bálint és Köllő (2008) rámutattak arra, hogy a jelenlegi gyermektámogatási rendszer már nem csak azt a célt szolgálja, amit a kezdetekben, azaz a kieső jövedelmet pótolja, hanem az alacsony iskolai végzettségü és kevés munkatapasztalattal rendelkező nők számára munkanélküli és szociális segélyként müködik. Nagy (2009) is megállapítja, hogy gyermeknevelési támogatások rendszerét nemekre semlegesen alakították ki, azaz férfiak és nők egyaránt igénybe vehetnék, de a gyermeknevelési szabadságon szinte kizárólag nők találhatók Magyarországon. A nők munkaerőpiacra történő belépésével a családi munkamegosztás csak igen kis mértékben változik meg, a nők hagyományos családi feladatai, szerepei megmaradnak (Szücs, 2005). Hasonló véleményen van Nagy és Primecz (2010) is, szerintük a hagyományos társadalmi normák továbbra is azt a képet erősítik, hogy a nők számára a legfontosabb feladat a család ellátása, míg a férfiak a család anyagi biztonságáért felelősek.

A feminista elméleti keretben a női munkaképesség és a nők elnyomásának megszüntetése kulcsfontosságú. Fontos, hogy ne essenek az emberek a nőies nő, férfias férfi előfeltételezés csapdájába, hanem tudatában legyen a nemek közötti különbségek történeti és társadalmi voltának. „A feminizmus tehát mindenképpen a nők (és egyre inkább a férfiak helyzetével is) foglalkozó elmélet/mozgalom/ideológia, amelynek központi eleme a férfiak és nők közti egyenlőtlen társadalmi és gazdasági viszony" (Nagy - Primecz 2010, p. 3.). Napjainkban a nemek kutatása önálló tudományterületként kezelendő, a gender studies szakirodalma egyre bővebb és jelentősebb.

\section{A kisgyermekes nőkkel foglalkozó korábbi kutatások}

A primer kutatás eredményeinek ismertetése előtt áttekintettük azokat a korábbi években megjelent magyarországi és külföldi kutatók tollából származó kutatási eredményeket, amelyek szintén a kisgyermekes nők munkaerő-piaci helyzetével foglalkoztak. (Az áttekintés nem teljes körü a téma sokszínűsége miatt.)
Az elmúlt évtizedekben a nők munkaerő-piaci részvétele növekedett az Európai Unióban, de még mindig alacsonyabb a férfiakénál. Ennek a különbségnek az okai részben a kulturális és társadalmi normákban gyökereznek, de tükröznek társadalmi és gazdasági kihívásokat is. Az elöregedő népesség globális kihívásai jelen vannak, amelyek lefelé irányuló nyomást helyeznek a munkaerő-utánpótlásra, az alapvető megélhetésre és a háztartások kiadásaira. Az anyák munkaerő-piaci részvételi aránya azonban jelentősen alacsonyabb, mint a többi nőtársaiké. A családi felelősséggel rendelkező nők egyharmada részmunkaidőben dolgozik vagy pedig inaktív. Ezek azt bizonyítják, hogy a gyermekfelügyelet egyenlőtlen megoszlása a férfiak és a nők között a legfőbb akadálya a gazdasági emancipációnak. Egyet értünk a Nagy - Primecz szerzőpáros (2010) véleményével, miszerint a nők és a férfiak között meglévő társadalmi különbségek nem biológiailag determináltak, hanem a társadalom tagjai építik fel és tartják fenn. A legtöbb nő számára nehéz összeegyeztetni a munkát és a gyermek(ek)kel töltött időt. Ugyanakkor, azokban a családokban, ahol csak egy szülő dolgozik, vagy az egyszülős családokról beszélünk, sokkal nehezebb ezt a dilemmát megoldani.

Garcia-Moran (2010) tanulmányában kérdésként fogalmazta meg, hogy melyek azok az eljárások, amelyek segíthetnek a családoknak, hogy egyensúlyba hozzák a családi életet a munkával? A háztartásokat és a gyermekvállalást vizsgálta, megállapította, hogy a háztartások a gyermekeikbe fektetnek és megosztják az idejüket a munka, a gyereknevelés és a szabadidő között. A gyermekgondozást az anyák munkaerő-piaci részvételének akadályaként mutatta be, ezzel vitatkozni lehet, hiszen a munkavállalás elötérbe helyezése a gyermekvállalással szemben hosszú távon még tovább rontja az amúgy is kedvezőtlen demográfiai folyamatokat Európában.

Zoltayné és Nagy (2013, p. 5.) felmérésük eredményeképpen megállapították, hogy ,a nők valamivel nagyobb fontosságot tulajdonítottak a kreativitásnak, mint a férfiak.” Egyes munkakörökben a munkavégzés során kiemelt szerepe van a kreativitásnak.

A női hallgatók vállalkozói hajlandóságának vizsgálatát végezte el Koltai és Szalka a 2011-es GUESSS-felmérés alapján, és az alábbi eredményeket állapították meg: „Közvetlenül a tanulmányok befejezése után többnyire az alkalmazotti létet választják, majd öt év elteltével, kellő tapasztalat és megfelelö kapcsolatrendszer birtokában nagyobb arányban kívánnak saját vállalkozást alapítani, illetve egy meglévőt átvenni. Másrészt a családalapítás is erre az időszakra tehető. A nők később vállalnak gyermeket, úgy gondolják, a munkát és a családot vállalkozóként könnyebben össze tudják egyeztetni... a nem gazdasági motivációk hangsúlyosabbak a nők esetében" (Koltai Szalka, 2013, p. 78.).

Koncz Katalin (2016) tanulmánya a női karrierutakat mutatja be, három fö karriertípust különít el: családi karrier, munkaerő-piaci karrier és kettős kötődésű karrier. A munkaerő-piaci karrierre koncentráló és a kettős kötődésű karriert megélő nőkre egyaránt jellemző az esélyegyenlőség hiánya a munkaerőpiacon, amely a férfiakénál 
gyengébb munkaerő-piaci pozíciókat eredményez. „A nők munkaerő-piaci pozíciója a férfiakénál gyengébb. Iskolázottságuk, szakképzettségük, munkahelyi gyakorlatuk, valamint kapcsolati tőkéjük és a hatalmi hálózatban való elhelyezkedésük határozza meg" (Koncz, 2016, p. 35.). Tanulmányában felhívja a figyelmet arra, hogy a nők társadalma nem homogén, eltérők az érdekeik és a nőpolitika, valamint a családpolitika összehangolása szükséges.

A növekvő női munkaerő-piaci részvétel segíthet csökkenteni néhányat a fent bemutatott kihívások közül, továbbá biztosítaná azt, hogy a munkaerö-potenciált jobban hasznosítsuk össztársadalmi szinten. Azonban számtalan dolog befolyásolhatja egy egyén döntését arról, hogy teljes munkaidős állást vállal-e, vagy részmunkaidőset.

Jelen tanulmányban a kisgyermekes anyák munkaerő-piaci lehetőségeit vizsgáljuk meg, és azt, hogy hogyan ítélik meg saját munkaerő-piaci visszatérésüket és lehetőségüket.

\section{A nők munkaerő-piaci helyzetét bemutató statisztikai adatok elemzése}

Frey a rendszerváltás utáni magyarországi munkaerő-piaci adatsorok vizsgálatakor megállapította, hogy az elemi foglalkozások szintjén a nők elkülönülése fokozottan megfigyelhető, ami a horizontális szegregációra utal. Az egyes munkakörökben a férfi többlet jelenléte pedig a vertikális szegregáció meglétét bizonyítja. Ez a helyzet nem változott tíz év alatt sem (Frey, 2001).

A nők munkaerő-piaci pozícióját befolyásoló tényezők közül ki kell emelni azokat a tényezőket, melyeket adottságnak kell tekintenünk, úgymint a munkaerőpiacon meglévő horizontális és vertikális szegregációt. A szegregáció a gazdasági élet minden területén megjelenik, kialakulnak a tipikus női és férfi pályák. A horizontális szegregáció során azt tapasztaljuk, hogy a nők más-más gazdasági területen, szektorokban, foglalkozásokban dolgoznak, más pályán indulnak el, mint a férfiak. Ahol nagy számban foglalkoztatnak női vezetőket, ott leszorítják a kereseteket, és így a férfiak nagyobb arányban távoznak

1. ábra

A foglalkoztatási ráta (\%) alakulása a 15-64 éves népesség körében (1998-2015)

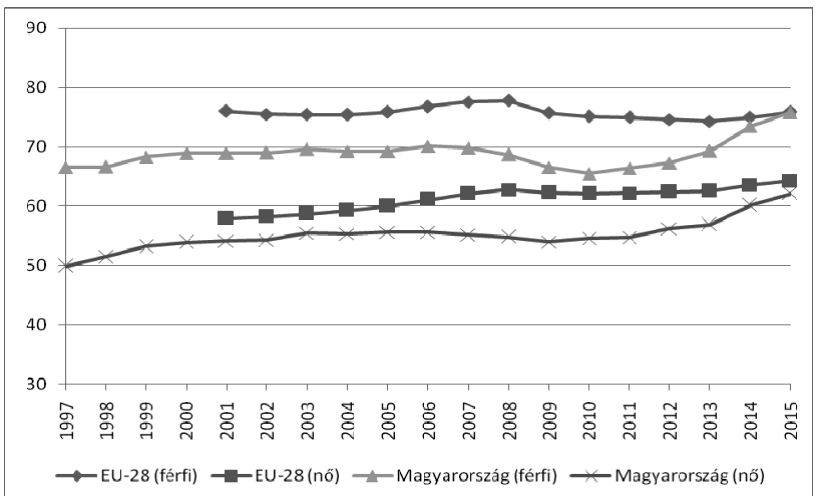

Forrás: Saját szerkesztés Eurostat adatok alapján ezekből a foglalkozási ágakból (Nagy, 1997). A vertikális szegregáció a foglalkozási hierarchiában való előrejutási lehetőségeket foglalja magában, azt, hogy a beosztási szinteken egyre feljebb haladva jelentősen csökken a nök aránya annak ellenére, hogy megfelelő formális képzettséggel rendelkeznek és a pozíció betöltésére formálisan megfelelö szakemberek között sem kisebb az arányuk, mint a férfiaké.

A munkaerőpiacon a két nem foglalkoztatási rátája között tartósan jelen van egy állandósulni látszó rés (1. ábra).

Magyarországon a férfiak foglalkoztatási rátája a 2008. évi gazdasági válságig enyhe növekedést mutatott, majd a válságot követően a 2000-es évek állapotára esett vissza. A válság miatt az építőipari és az autóipari dolgozókat bocsátották el nagyobb arányban. 1998-2008 között enyhe növekedés, majd stagnálás volt megfigyelhetö, viszont a válságot követően a csökkenés a hazai foglalkoztatási adatokban is megjelent, de 2011-től elég dinamikus növekedést tapasztalhatunk, ennek magyarázata a közfoglalkoztatási program újragondolása és a válságból való kilábalás eredményeképpen az ipari szektor megerősödése. A nők esetében sokkal alacsonyabb szinten valósul meg a foglalkoztatás. A gazdasági válság a női foglalkoztatási adatokban kevésbé figyelhető meg, mint a férfiak adataiban, hiszen a válság inkább a nagyobb arányban férfiakat foglalkoztató ágazatokat sújtotta. A tendencia eltérő az európai uniós átlag esetében, ott ugyanis a gazdasági válság után elindult egy enyhe visszaesés, majd 2009-től stagnálás figyelhető meg. 2015-re a hazai férfi foglalkoztatási ráta elérte az uniós átlagot, köszönhetően a közfoglalkoztatásnak.

2. ábra

A munkanélküliségi ráta (\%) alakulása az aktív népesség körében (1998-2015)

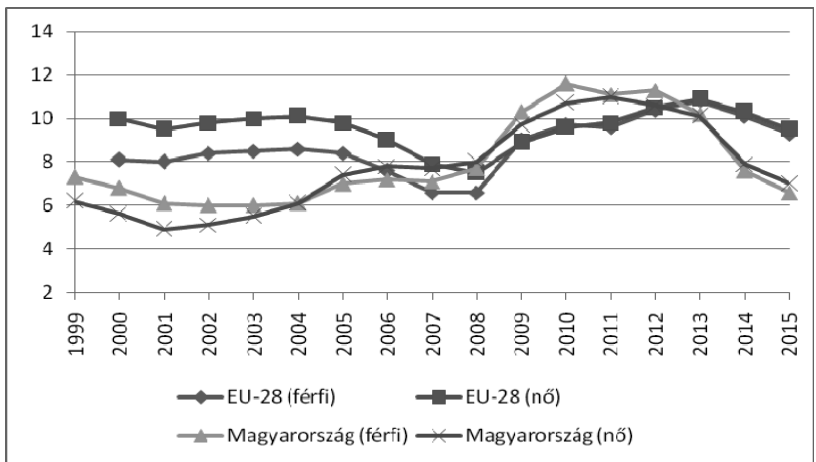

Forrás: Saját szerkesztés Eurostat adatok alapján

A munkanélküliségi ráta (2. ábra) vizsgálata is érdekes eredményeket ad, Magyarországon 1998-2001 között mind a nők, mind a férfiak munkanélkülisége csökkent, majd 2001-2004 között enyhe növekedés jelent meg, 2005-2008 között stagnálás és 2008-2011 között drasztikus növekedés, majd 2011-től drasztikus csökkenés. A férfiak munkanélkülisége a vizsgált időszakban szinte végig a nők munkanélküliségétől magasabb értékeket adott, kivéve 2005-2008 közötti időszakot. Az unió esetében a tendencia eltérő és 2013 óta a hazai munkanél- 
küliségi adatok az uniós átlag alatt maradtak (Lipták Matiscsákné, 2016).

Az uniós adatok áttekintése után a magyarországi munkaerőpiac három fő indikátorát illesztettük egy ábrába a férfiakra (3. ábra), majd a nőkre (4. ábra).

3. ábra

A magyarországi munkaerő-piaci adatok alakulása a férfiaknál a 15-64 éves népesség körében (1998-2015)

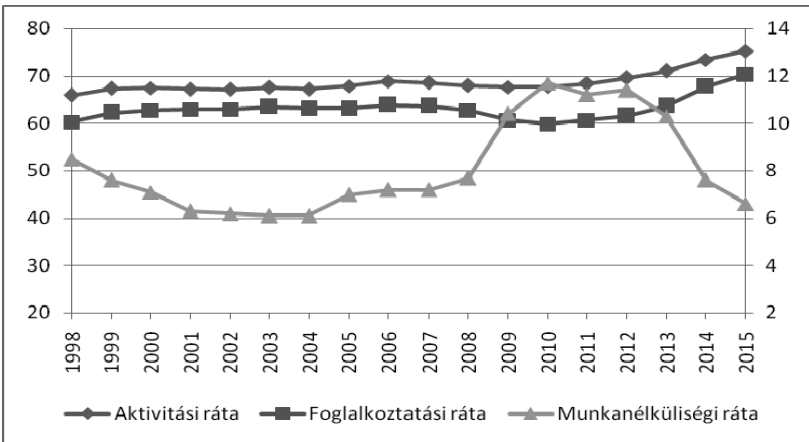

Forrás: Saját szerkesztés KSH-adatok alapján

A férfiak és a nők adatsorait összehasonlítva jól látszik, hogy az aktivitási és a foglalkoztatási ráta (bal oldali tengely) ugyanolyan tendenciát követ, de a nök esetében 15 százalékponttal alacsonyabb szinten vannak az értékek. A munkanélküliségi ráta (jobb oldali tengely) viszont eltéréseket mutat. A munkanélküliségi ráta folyamatos növekedése ellenére a nők foglalkoztatása nem vagy kevésbé esett vissza a gazdasági válság alatt, mint a férfiaké.

4. ábra

A magyarországi munkaerő-piaci adatok alakulása a nőknél a 15-64 éves népesség körében (1998-2015)

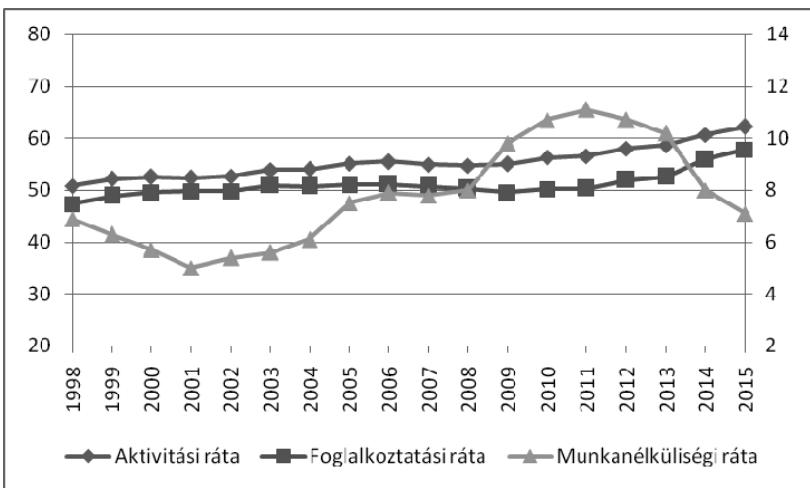

Forrás: Saját szerkesztés KSH-adatok alapján

Mint azt a fenti adatok mutatják, a nők valóban egyre nagyobb mértékben vannak jelen foglalkoztatottként a munkaerőpiacon. Felmerül a kérdés, hogy a nőket lehet-e egységes, homogén csoportnak tekinteni, vagy mindenképpen célszerü szegmentálni őket. Mi a következőkben a nők gyermekszám szerinti foglalkoztatottságára térünk ki, hiszen ez a szempont fontos befolyásoló tényező a munkaerőpiacon (5. ábra).

\section{A 25-49 éves nők foglalkoztatási rátája Magyarországon a gyermekek száma alapján, \% (2003-2016)}

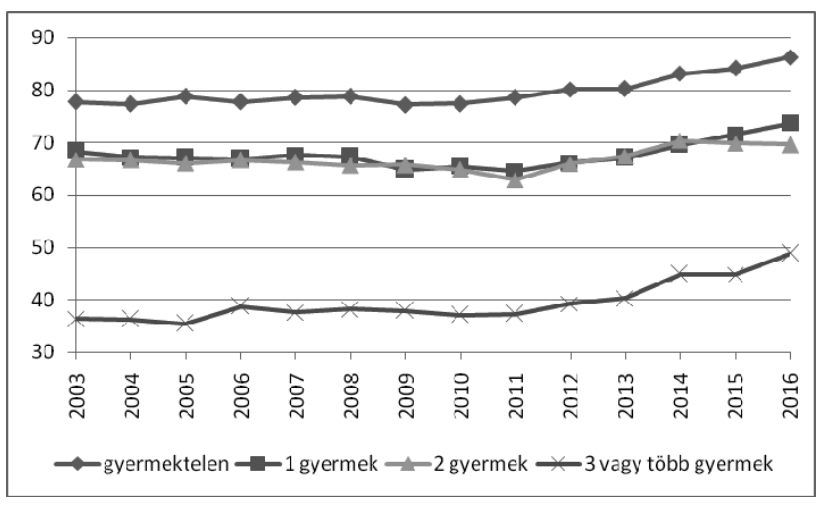

Forrás: Saját szerkesztés KSH-adatok alapján

A kisgyermekes anyák otthonmaradását lehetővé tevő családpolitika nagymértékben kihat a kisgyermeket nevelő anyák munkaerő-piaci részvételére. A gyermektelen, egy és két gyermeket nevelő nők esetén $70 \%$ és $86 \%$ közötti a foglalkoztatási ráta, míg a 3 vagy több gyermekes anyák csupán 48\%-a dolgozott 2016-ban. Ha a családban 3 vagy annál több gyermek van, akkor az anya foglalkoztatási rátája az EU-ban 2 százalékponttal, míg hazánkban 12 százalékponttal alacsonyabb az átlagnál 2013-ban. A fenti adatok egyértelműen rávilágítnak arra, hogy a gyermekek számának növekedésével a nők munkaerő-piaci esélyei romlanak. Ez egyrészt betudható annak a sztereotípiának, hogy a kisgyermekes női munkavállaló nem annyira rugalmas, hiszen a gyermekellátó intézmények (bölcsőde, óvoda, iskola) nyitva tartása nem minden esetben illeszkedik a munkahelyek munkaidejéhez, illetve a kisgyermekes anyákról a munkáltatók eleve azt feltételezik, hogy az átlagosnál többet fognak hiányozni a gyerekek betegsége miatt. A kisgyermekes nők a gyermekvállalás után nehezen tudnak visszatérni a munka világába még akkor is, ha a kormányzat számos család- és foglalkoztatáspolitikai eszközzel segíti őket a munkába történő visszatérésben (Vajda, 2014).

Ha a női foglalkoztatási rátát megnézzük az EU-ban, azt tapasztaljuk, hogy ott jobb a helyzet, hiszen 2013-ban a női foglalkoztatási ráta átlagosan $62,6 \%$, míg hazánkban $57 \%$ volt. Az átlagok ugyanakkor eltakarják a nöi munkavállalói szegmenseket, hiszen nem mindegy, hogy a teljes munkaidőben dolgozókat, a 3 vagy annál több gyermekes anyákat, illetve a 6 év alatti gyermeket nevelő anyák foglalkoztatási adatait vizsgáljuk. 2013-ban a teljes munkaidőben foglalkoztatott nők aránya a 15-64 éves korosztályban Magyarországon 48,2\% és ez magasabb, mint az EU-ban, ahol 39,4\%. Felvetődik a kérdés, hogy vajon ez az adat azt jelenti, hogy az EU-ban inkább család- és nőbarát a munkaerőpiac, vagy a rendszer inkább a nem hosszú otthonmaradást, hanem az atipikus foglalkoztatást, benne a részmunkaidős foglalkoztatást részesíti előnyben. 


\section{A fókuszcsoportos vizsgálat bemutatása és az eredmények értékelése}

A fókuszcsoportos vizsgálattal a kisgyermekes nők munkaerő-piaci esélyeit befolyásoló tényezőket tárjuk fel, illetve rávilágítottunk a legfrissebb statisztikai adatokkal arra, hogy a gyermekek számának növekedése egyre nagyobb hátrányt jelent a nők foglalkoztatottságában. Ha a nők foglalkoztatási arányát vizsgáljuk a gyermekek száma szerint, akkor a gyermektelenek körében volt a legmagasabb a foglalkoztatottság és a gyermekszám növekedésével párhuzamosan csökkent ez az érték.

A kisgyermekes nők munkaerő-piaci hátrányának okait kívántuk egy fókuszcsoportos vizsgálattal feltárni, megismerni és az érintettek bevonásával megérteni. A két érintett célcsoport, egyrészt a kisgyermekes anyák, mint munkavállalók, másrészt a HR (emberi erőforrással foglalkozó) szakemberek, akik a munkaadói oldalt képviselve veszik fel a munkavállalókat. A fókuszcsoportos vizsgálatot hatékony módszernek tekintjük, egyrészt a szakirodalomban leírtak alátámasztására és kiegészítésére, másrészt megalapozása lehet egy további kutatásnak, hiszen alkalmas az okok és a motivációk feltárására. Megalapozó kutatásként akarjuk használni ezt a módszert a téma jövőbeli kutatásához, hiszen szeretnénk további primer kutatást végezni az érintett két célcsoport - kisgyermekes anyák/szülök, illetve HR-szakemberek - körében és így a kapott eredmények segíthetik, támogathatják a strukturált kérdéseket tartalmazó felmérés kérdés- és válaszkategóriáinak meghatározásait is.

Az interjúk egyik csoportja a társadalomtudományos csoportinterjú, ennek leggyakrabban alkalmazott típusa a fókuszcsoport, azaz olyan csoportos beszélgetések, amelyek egy téma köré fókuszáltak és moderátor vezeti (Vicsek, 2017). Jelen esetben ez egy klasszikus fókuszcsoportos vizsgálat volt, melynek lényege, hogy egymást korábbról nem ismerő, kifejezetten az adott alkalomra kiválasztottak vesznek rajta részt, akik kontrollált körülmények között találkoznak és egy moderátor támogatásával a kutató által meghatározott témákról 90 percen keresztül beszélgetnek. Olyan társadalomtudományos adatgyüjtési módszer, amely a vélekedések interakcióján (akár vitahelyzeteken) keresztül igyekszik megismerni a fókuszba állított szituációk és jelenségek résztvevői/érintetti percepcióját (Vicsek, 2006).

Jelen esetben egy fókuszcsoportos vizsgálatra került sor, kisgyermekes anyákat és HR-szakembereket hívtunk meg 2016. november 18-án 15 órakor Miskolc belvárosába, a Miskolci Nőknek Is Esélyt Alapítvány irodájába. A fókuszcsoporton 11 fó vett részt, 5 fö kisgyermekes, 4 fö HR-munkatárs és 2 fö kutató szakember, mindannyian nők. (A résztvevők demográfiai jellemzőit az 1. melléklet tartalmazza.) A fókuszcsoport levezetésében mindkét kutató részt vett mint moderátor, az egyik a munkaadói, míg a másik kutató a munkavállalói oldalt irányította. A két alcsoport között a beszélgetés során kialakult egy közös párbeszéd, nem különült el a két csoport, de a moderátorok figyeltek arra, hogy a vélemények forrása jól azonosítható legyen.
A tartalom elemzéséhez csak tartalmi kivonatot, ún. kiiratot készítettünk (Vicsek, 2006). A legépelt változatot a vezérfonalban szereplö kérdések alapján dolgoztuk fel, ezért úgy tünhet, hogy ,interjúszövegeket” írunk le, de ezek a tipikus és atipikus válaszok. A fókuszcsoportos eredmények kvantifikálásának érvényessége igen kérdéses, így erre nem is törekedtünk, hiszen a megkérdezettek száma csekély, nem éri el a statisztikai elemzésre alkalmas elemszámot, illetve a meghívottak sokasága sem tekinthető statisztikai mintának. A legfontosabb azonban az, hogy az elhangzó vélekedések nem függetlenek egymástól, és egy-egy résztvevő véleménye is dinamikusan változik egy beszélgetés során. A fókuszcsoportos beszélgetés félig strukturált kérdéslista alapján történt, az elöre megfogalmazott kérdéseket a 2. melléklet tartalmazza.

A kérdések és az azokra adható válaszok nem követték szigorúan a témavázlatban foglaltakat, a moderátorok bár a témavázlat alapján irányították a beszélgetést, a beszélgetés menete ettől többször eltért. A kapott eredményeket a munkavállalói és a munkaadói oldal véleményének, gondolatainak az összegzésével foglaljuk össze, majd javaslatokat fogalmazunk meg mindkét célcsoport számára. A fókuszcsoporton elhangzottak egyértelmüen rávilágítottak arra, hogy a munkaeröpiac két szereplője, a munkavállaló (esetünkben a kisgyerekes anyukák), és a munkaadó (jelen esetben a HR-esek) teljesen máshogy látja a foglalkoztatási helyzetet.

A kisgyermekes anyák véleményei és gondolatai önmagukról és az elhelyezkedési esélyükről az alábbiakban foglalható össze. Az elmúlt évek munkaerő-piaci változásai, a 2008. évi válság, a 2010. évet követő nők elhelyezkedését segítő kormányzati támogatások, a megjelenő munkaerőhiány kicsit megkönnyítették a nők, elsősorban a kisgyermekes anyák visszatérését, de alapvetően egyén függő, hogy ki, hogyan tud a munkaerőpiacra visszatérni. ,,Többször próbáltam beszélni a munkaadómmal, hogy visszamennék négy órában, mert kell a pénz, de nem volt hajlandó visszavenni. Azt mondta, van most a helyemen egy idösebb hölgy, aki megbízható, nem akarja elküldeni"- mondta az egyik interjúalany és nem is ment oda vissza, új cégnél helyezkedett el. A kisgyermekes nők általában megbízható munkaerőnek tartják magukat, akik megbecsülik a munkahelyüket, elkötelezettek és ritkán váltanak, mert sokat kockáztatnának. „Engem is hívtak, hogy menjek át, de nem mentem"..." azért, mert már megszoktam a társaságot, tudtuk egymás rezdüléséböl, mit akar ...egy jó csapat voltunk... nem akartam újra kezdeni...."- mondta egy másik alany. Egy családot irányító nő jó szervezőkészséggel, hatékony időgazdálkodási képességgel rendelkezik, mert megtanulta a magánéletben, a családban (is), hogy a feladatokat időben kell elvégezni. „És nem is gondolják a férfiak, milyen nehéz a gyerekek logisztikája, hogy mind a három gyerek eljusson oda, ahová kell ...úszás, tánc, külön angol... ez a férfiaknak természetes, saját autóval nekem még egyszerü is, busszal nem tudom, hogy tudnám megoldani”- mondta az egyik alany. Egyszerre többfelé képes figyelni egy kisgyermekes nő, ahogyan azt otthon is teszi: főz, mosogat, tévét hallgat, a gyerekkel beszélget és mindezt egyszerre?! Többen 
tudatosan készültek a munkaerő-piaci visszatérésre és az otthon töltött idő alatt tanultak, fejlesztették magukat, mert érezték, hogy nem maradhatnak le, ha vissza akarnak térni a munka világába. „Én nagyon sokat olvastam, bár többen mondták, hogy két gyerek mellett erre nem lesz idöm, és megtanultam a számítógépet is sokkal jobban kezelni, mert látom, hogy e nélkül nem lehet élni, a telefonhoz is kell egy csomó mindent tudni...." - mondta az egyik alany, aki nagyon szeretné az újonnan megszerzett (szak) tudását a munkaerőpiacon is hasznosítani. Általában igaz, hogy motiváltak a kisgyerekes nők az elhelyezkedésben, meg akarják mutatni, hogy nem „csak” a gyermeknevelésben jók, hanem a munkában, a szakmájukban is teljesíteni akarnak. ,Vannak olyan férfiak, akik szerint a nönek a fakanál mellett van a helye ...szerintem ez a múlt, mert nekem is és a többi nönek is vannak egyéni igényeink, hogy megbecsüljenek"- háborodott fel az egyik alanyunk. Tapasztaljuk kutatóként is, hogy valóban sok nő (a megélhetésen túl) önmegvalósítási, elismerési igényeinek kielégítése érdekében vállal munkát, hogy megmutassa, hogy értékes és hasznos tagja a társadalomnak.

A kisgyermekes nők sokszor félnek a munkaerőpiacra történő visszatéréstől, egyrészt tartanak a munkaadókkal való találkozástól, a munkahelyi konfliktusoktól, előítéletektől és attól, hogy nem tudnak megfelelni az elvárásoknak. A félelmeik erősek, gyakran azzal magyarázzák, hogy több éve otthon vannak, nincsenek igazán „munkaadói" kapcsolataik, hiszen nem tartják a kapcsolatot a régi/volt/ahonnan eljöttek munkaadóval, és ezért így, hogy menjenek oda vissza. Korábbi kutatások (Szücs, 2005; Frey, 1996) is megállapították a kapcsolati háló gyengülését.

Büntudatuk van, és nem tudják, hogy mikor szóljanak, hogy visszamennének dolgozni, hiszen már van a helyükön valaki más, akkor most azt az embert miattuk fogják elküldeni. A gyermeknevelés alatt nem képezték magukat sem szakmai elméletben, sem a ma már fontos informatika területén, ezért tartanak attól, hogy most már mindent számítógépen kell csinálni és nem biztosak abban, hogy meg tudják-e majd csinálni a kapott szakmai feladatokat.

Az anyák nem tudják még elképzelni sem, hogy fogják összeegyeztetni a munkát a családdal, a házimunkával, felmerül bennük, hogy ha visszatérnek a munkába, akkor ki fogja elhozni a gyereket a bölcsödéböl, óvodából, iskolából, hogy tudnak majd mindent megcsinálni, mint eddig otthon, segítség nélkül: „Amíg otthon voltam a kicsivel, könnyebb volt a nagyobb gyereket is elvinni a suliba, majd érte menni. Ha újra dolgozni fogok, nem tudom, hogy fogjuk megoldani... a férjem segitsége is kell majd." Félnek az új munkahelytől, mert több esetben a régi már megszünt, vagy a vezető és a kollégák mit fognak szólni, ha beteg lesz a gyerek, nem tudnak túlórákat vállalni, mert nincs, aki elhozza a gyermekellátó intézményből, aminek persze kötött a nyitva tartása, de több müszakot, vagy hétvégi müszakot sem tudnak vállalni, mert nincs kire hagyni a gyereket.

Szívesen visszamennének részmunkaidőben is dolgozni, hiszen erre a jogszabályok lehetőséget adnak, de azt hallják, hogy egyrészt erre nincs nagyon lehetőség, és ha van is, akkor vagy csak papíron, azaz ugyan úgy több mint 8 órát kell dolgozni, vagy a kereset olyan alacsony, hogy abból nem lehet megélni, hiszen sok, gyermekét egyedül nevelő anyukáról beszélünk. A jól szabályozott részmunkaidő valós megoldást jelentene a kisgyermekes anyák számára.

Nem tartják család- és nőbarátnak a mai munkaadókat, minden cég maximálisan ki akarja használni a dolgozókat, kevés munkavállalót foglalkoztatnak, sokszor kell túlórázni, túlterhelik munkával a dolgozókat, többen még hazaviszik a munkát és otthon csinálják meg, de ezt kisgyerek mellett nem tudják vállalni. „Pedagógusként gyakran hazaviszem még most is a dolgozatokat, inkább otthon javitom ki azokat és közben meg is fözök, meg a mosógépet is beinditom,...de a barátnöm bent könyvel, ö ezt nem teheti meg, bevalláskor estig bent marad a munkahelyén..."- támasztja alá az egyik alany az előző gondolatokat. Kirekesztődnek a munkahelyi közösségből, mert nem tudnak a többiekkel tartani, munka után beszélgetni vagy szórakozni. Ezt erösítette meg az egyik alanyunk: „Igen, többször elöfordult, hogy nem mentem el egy munkatársam névnapját munka után megünnepelni, nem azért mert nem akartam, hanem azért, mert idöre kellett az óvodába beérnem a gyerekért."

Kíváncsiak voltunk arra is, hogy mit és milyen munkahelyet szeretnének a kisgyermekes nők. A válaszok nagyon egyszerüek és tömörek voltak: ,Visszamenni a régi munkakörbe.” „Atipikus foglalkoztatási formákat (részmunkaidö, távmunka, osztott munkaidö).” „Egymüszakos munkarendet.” „Rugalmas munkaidöt.” „Rugalmasabb munkaszervezési formákat.” „Képzési lehetőség biztosítását (amely megfelelöen illeszkedik a munkaidöhöz).” „Elfogadó, megértö munkakörnyezetet (vezetöt, beosztottakat)." A félelmeik miatt a kisgyermekes nők egy része halogatja a munkába történő visszatérést, mások ugyan elindulnak, de gyakran falakba ütköznek és a falat gyakran a munkaerőpiac másik szereplőjének a képviselője, „kapuja” jelenti: a HR-szakember.

Összességében a kisgyermekes anyák egyértelműen megfogalmazták, hogy nagyon személyiség- és helyzetfüggő, hogy kisgyermek mellett ki, mikor, hová és milyen feltételekkel tud visszamenni dolgozni. A nők nem egységesek, nem lehet általánosítani, erre még tanulmányunk végén visszatérünk.

A HR-szakemberek kisgyermekes anyákkal és elhelyezési esélyeikkel kapcsolatos gondolatait és véleményeit a következőekben mutatjuk be. A HR-szakemberek által elmondottak két témakör köré csoportosíthatók: egyrészt, hol hibáznak a kisgyermekes nők a munkaerőpiacra történő visszatérésükkor, másrészt mit tesznek/tehetnek a cégek a kisgyermekes nők támogatása érdekében, azaz milyen megoldási javaslatok léteznek a gyakorlatban.

Kíváncsiak voltunk, hogy milyen hibákat követnek el a kisgyermekes, munkaerőpiacra visszatérő anyák. A legfontosabb, hogy létezik egy olyan csoport, akiknek nincs kidolgozott, végiggondolt tervük a visszatérésre: mikor, melyik munkaadóhoz és milyen pozícióba akarnak visszamenni. Nem tudják, hogy a gyerek születése után mikor akarnak visszatérni a munkaerőpiacra, gyakran az 
utolsó pillanatban - a gyes lejárta előtt - gondolja át az anya, hogy mi is lesz a munkába állással, azt sem tudják, hogy a régi munkaadóhoz akarnak-e visszamenni, vagy újat keresnek, milyen pozíciót tudnak reálisan betölteni. ’Jött egyszer egy kétgyerekes anyuka az állásinterjúra, de ez többször is elöfordult már és arra a kérdésre, mivel szeretne pontosan foglalkozni az volt a válasza, hogy teljesen mindegy, csak már nem akar otthon maradni, bármit elvállal" - mondta az egyik HR-es.

Nincs hatékony álláskeresési technikájuk: rossz az önéletrajzuk (beleírják a családi állapotukat, a gyerekeik számát, életkorát), nem elég határozottak az állásinterjún (ha rákérdeznek, hogy a gyerekkel járó gondokat meg tudják-e oldani, a válaszok gyakran bizonytalanok). Nincs, vagy hiányos a számítógépes tudásuk: nem tudnak online állást keresni és jelentkezni, vagy nagyon gyakori, hogy nem megfelelő e-mailcímet használnak (a férj címére várják a választ, vagy „,komolytalan” e-mailcímük van. „,Ami a legmegdöbbentöbb, hogy még a fiatal álláskeresö sem tudja, hogy nem mindegy mi az e-mailcíme, amiröl az önéletrajzát küldi, egyszer egy cicuska18-ról kaptam e-mailt, hát...be sem hívtam a lányt, pedig már gyerekes anyuka volt...hihetetlen"- mesélte a tapasztalatait egy HR-es.

Nem reális az önértékelésük: nem tudják, mit jelent, hogy az otthon töltött időszak alatt megkopik a szaktudásuk, a kapcsolatrendszerük. ,Egyszerüen nincsenek a nők tisztában azzal, mit tudnak és mit érnek. Az nem elég, hogy két éve tisztességgel neveli otthon a gyerekeket, ellátja öket, hanem tudnia kellene az anyukának nem csak gyerekekkel kapcsolatos dolgokról is beszélgetni...Nem hallgatnak híreket, nem olvasnak, nincsenek tisztában a napi történésekkel...csak a gyerek, mit eszik meg és mit nem......hát így tényleg nem vesszük fel, legyen érdeklödö, kíváncsi és motivált.....mert ha nem tudja, majd megtanulja, de ha nem érdekli, akkor a munkához is így fog hozzáállni? '”- foglalja össze a témakört az egyik HR-szakember.

Figyelmen kívül hagyják a munkáltató szempontjait: azaz hogy a munkáltató rugalmas és terhelhető munkavállalót akar. Nem tudják jól beosztani az idejüket: meg, (újra) kell tanulni, hogyan kell összeegyeztetni a munka és a magánéleti feladatokat, hogyan osszák meg/be a feladatokat a munkahelyen és otthon. Nem kommunikálnak nyíltan a munkaadóval: félnek a munkáltató reakcióitól. Határozottan el kell mondani, hogy kisgyermekes és ezt nem hátrányként kell megélnie az anyukának, célszerü tájékoztatni a munkáltatót, hogy meg tudja oldani a gyermek/gyermekek elhelyezését, mert van családi, baráti háttér, aki a segít ebben.

A nők és férfiak közötti társadalmi egyenlötlenségek hátterében a nőkkel szembeni diszkrimináció jelensége áll (Vajda, 2014). A diszkrimináció gyakran észrevétlen, mivel beépül a munkaadó napi rutinjába és nem csak a diszkrimináció által érintett csoportoknak okoz hátrányt, hanem a munkaadóknak is. A magyar törvények szerint a munkaadó felelős azért, hogy ne diszkrimináljon és a gyakorlatnak megfelelően a HR-es szakemberek feladata, hogy cégen belül képviseljék a diszkrimináció tilalmát. Egyet értünk Krizsánnal és szerzőtársaival (2009) miszerint a diszkrimináció kezelése nem csak a megkülönböz- tetés elleni fellépés, hanem az értékformálódás miatt is aktív beavatkozást igényel. A 2003. évi CXXV. törvény az egyenlő bánásmódról és az esélyegyenlőség előmozdításáról szabályozza, hogy az egyéni szempontok azonos mértékű figyelembevételével kell eljárni az élet bármely területén, továbbá a törvény tiltja a hátrányos megkülönböztetést. A fókuszcsoportos interjú során a HR-szakemberek véleményében felfedezni véltük a diszkrimináció alkalmazását, noha nyíltan nem mondták ezt ki.

A fókuszcsoportos interjún a HR-szakemberek egyértelmüen megfogalmazták, hogy mit tesznek/tehetnek a cégek a kisgyermekes nők támogatása érdekében, azaz milyen megoldási javaslatok léteznek a gyakorlatban. A fókuszcsoporton elhangzottak és a szakirodalomban olvasott, illetve a gyakorlatban látott megoldási lehetőségek ismeretében (az egyik szerző maga is 3 gyermekes anyuka) az alábbi megoldási javaslatokat látjuk reálisnak. A diszkrimináció tilalmának betartását is reális megoldási javaslatnak tartjuk a fókuszcsoportos interjún elhangzottak alapján. A kisgyermekes anyáknak rugalmas foglalkoztatási megoldásokra van szükségük, ahogy azt több magyar kutató is megállapította már (Tóth, 1995; Bukodi - Róbert, 1999; Aranyi, 2000; Frey, 2001; Lakatos, 2001). Erre jó eszköz lehet a hazánkban még nem annyira elterjedt atipikus foglalkoztatás alkalmazása. Ilyen lehet a részmunkaidő, négy vagy hat órás foglalkoztatás, de sokszor még a hét óra is jó nekik. Meg kell említeni, hogy a skandináv területeken - ahol sokkal jellemzőbb az atipikus foglalkoztatás - nagyobb teret hódít az apák és az anyák megosztott gyermekgondozási feladatainak a létjogosultsága. Azaz az apák ugyanúgy elmehetnek szülési szabadságra, gondozhatják ők a gyermeket, miközben az anya teljes állásban dolgozik. Ilyen lehet még a távmunka, a home-office lehetősége, amely elvben hasonló, bár tartalmilag más, de mindkettő az otthoni munkavégzésen alapszik. Ennek az ellenörzési, nyomon követési rendszere sokszor viszszatartja a munkáltatókat. Nehézséget jelent az is ennél a munkavégzés-típusnál, hogy a munka és a magánélet/ otthon keveredik és ez képes gyorsan felörölni egy munkavállalót, illetve nehéz is elérni azt az egyensúlyt, hogy ne tolódjon el egyik irányba sem ez az arány. Alapvető gond még mindig a bölcsődei és az óvodai helyek, illetve elérhetőségek száma. Sajnos nem a megszokott munkaidőhöz van kötve az intézmények nyitvatartási rendje, nagyon nehéz így megoldani a nyolcórás munkavégzést. A megoldás az lehet, ha a cég maga müködtet vagy vesz igénybe saját dolgozói gyerekének ilyen szolgáltatást, és így tudja biztosítani a rugalmasabb nyitva tartást. Ha több müszakban is dolgoznak a munkavállalók a cégnél, akkor előfordul, hogy a vállalat úgy próbálja segíteni a kisgyermekesek teljes munkaidős foglalkoztatását, hogy részükre saját müszakot alakítanak ki 8:00-16:00 óra között. Természetesen az is egy valós megoldás, hogy a munkaidőrendszert rugalmassá teszi a szervezet, ilyen lehet a kötetlen és rugalmas munkaidő. Ezeket csak azoknál a pozícióknál lehet alkalmazni, amelyek tényleg flexibilisek, például általában a vezetői beosztásokban lehet kötetlen a munkaidő, azaz a munkavállaló elvég- 
zi a feladatait, de ő maga osztja be, mikor, mennyi időt tölt bent a munkahelyen. Egyes ügyintéző, irodai pozíciókban lehet alkalmazni a rugalmas munkaidőt, amikor van egy törzsidő megadva, pl. 10:00-14:00 óra, amikor a munkavállaló bent kell, hogy tartózkodjon a munkahelyén és előtte, és/vagy utána meghatároznak peremidőt, amit rugalmasan tölthet bent a munkavállaló és a kötelezően ledolgozandó órák számát hetente, vagy havonta nézik, hogy teljesítette-e.

A fókuszcsoportos interjún túl utánanéztünk, hogy milyen programok, díjak azok, amelyek a téma szempontjából fontosak. Ilyennek ítéltük a „Családbarát Munkahely-program" bevezetését, illetve müködtetését. Már több helyen hatékonyan müködik családbarát-program, aminek nem titkolt célja, hogy reflektorfénybe helyezze azokat a munkaadókat és gyakorlatukat, akik családbarát, munka-magánélet egyensúlyát támogató müködésükkel hozzájárulnak a társadalom családbarát szemléletének erősítéséhez, a gyermekvállalás támogatásához. Létezik „Az Év Családbarát Vállalata Díj”, ami alátámasztja, hogy ennek az elvárásnak van társadalmi szerepe is. A pályázat rávilágít arra, hogy milyen eszközökkel lehet segíteni a családos munkavállalókat: atipikus formákkal, gyereksarokkal, családi napközivel, munkaidö-kedvezménnyel stb.

Legjobb női munkahely kialakítása a „Legjobb Női Munkahely Díj” pályázati kiírása alapján, amelynek célja, hogy rámutasson a nők foglalkoztatásának esélyegyenlőségi szempontján túl a nők alkalmazásának gazdasági szükségszerüségére és jó példákat mutasson be, amelyeket más munkáltatók is átvehetnek.

A felelős foglalkoztatás egy terjedő szemléletmód, amellyel az utóbbi években hazánkban is találkozunk a vállalati felelősségvállalás (CSR) egyik szegmenseként, mely kiterjed a HR-stratégiák és az esélyegyenlőség területeire is. A profit megszerzésén túl olyan célok is megjelennek a foglalkoztatás kapcsán, mint például a dolgozók elégedettsége, jó munkahelyi közérzete, munkájuk és magánéletük összehangolásának támogatása. Ennek elterjedése két okra vezethető vissza: az egyik a nemzetközi trend, amely a multinacionális vállalatoktól gyürüzik a kis- és középvállalkozások irányába, a másik pedig a jól körülhatárolható imázsépítés, amely közvetetten ugyan, de komoly bevételt jelent a vállalatoknak. „Az Év Felelős Foglalkoztatója Vándordíj" szintén kijelöl irányokat, melyek segíthetik a kisgyermekesek foglalkoztatását is.

\section{A munka és a család összeegyeztethetősége}

A munka és a család, valamint a munka és a magánélet egyensúlyának fenntartása a kisgyermekes nők körében kulcsfontosságú. Primecz et al. (2014) arra hívják fel a figyelmet, hogy a szervezetek által alkalmazott munkavállaló-barát gyakorlatok nem csak pozitív irányban alakítják a munkavállalók elkötelezettségét és bizalmát, ugyanis munkakörönként, pozíciónként és nemenként eltérőek az elvárások. Nem lehet egyszerre minden munkavállaló elvárásának megfelelni, ezért a legtöbb vállalat munkavállaló-barát gyakorlata nem éri el a szervezet által deklarált célt.
A menedzsment szempontjából fontos, hogy különbséget tegyen a női, illetve a kisgyermekes női munkavállalók között, azok család- és karrierorientációja szerint, hiszen az eltérő szegmensbe tartozóknak alapvetően más elvárásaik vannak a foglalkoztatással kapcsolatosan.

6. ábra

A nők család- és karrierorientációs modellje

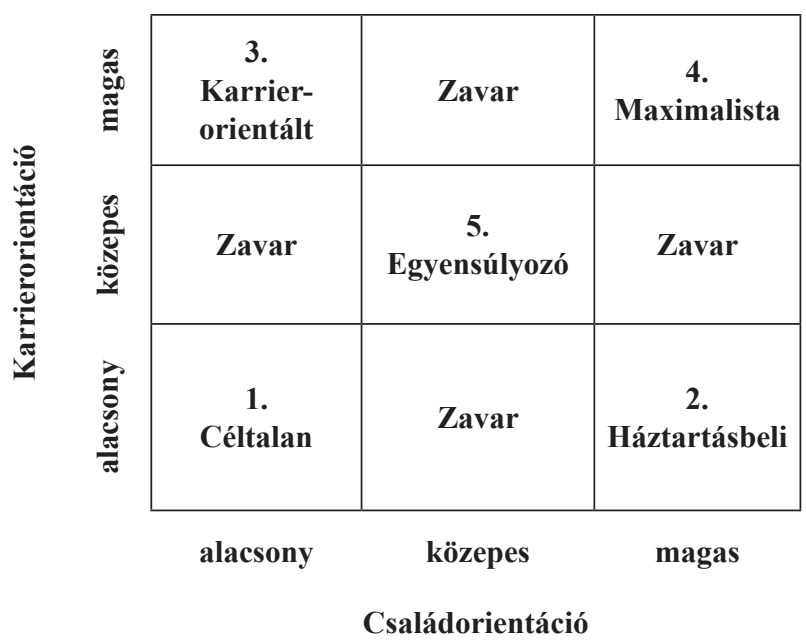

Forrás: Matiscsákné (2006)

A 6. ábra mutatja az öt szegmenst, csoportot, mint ahogy több mátrixban nem lehet értelmezni az alacsony-közepes, magas-közepes mezőket, mi sem tudjuk beazonosítani azokat a család- és karrierorientáció szerint, nem mutatnak homogén szegmenst, így e mezőkbe a „Zavar” került elnevezésként. A szegmensekbe tartozók főbb jellemzői és foglalkoztatási elvárásai:

1. csoport: Az első csoportba tartozó nők „,céltalanok”, nekik sem a család, sem a karrier nem fontos, sodródnak az árral. Ök általában gyermektelen fiatalok, aki rugalmasan tudnak reagálni a munkaerő-piaci elvárásokra, tudnak több müszakot vállalni vagy túlórázni. Ök azok, akik meg akarják alapozni az életüket, hajlandók fejleszteni magukat, de nem vállalják túl magukat, flexibilisek, de nem túlságosan motiváltak.

2. csoport: Van, akinek a család ellátása maximálisan fontos, ezért feladja a munkát, vagy nem is vállal munkát és háztartásbeliként éli az életét. Ezzel azt kockáztatják a nők, hogy tartósan kiszorulnak a munkaerőpiacról és kiszolgáltatott helyzetbe kerülnek, a férjek tartják el őket, ami a válások magas számának ismeretében igen kockázatos. Ezeket a nőket akkor lehet visszavonzani a munkaerö-piacra, amikor a gyerekek már nagyok, de ahhoz hogy foglalkoztathatók legyenek, támogatni kell őket a munkaerőpiaci reintegrációban, például a kompetenciadeficitjük csökkentésében képzéssel és kezdetben részmunkaidős alkalmazással. Akik tartósan kiszorulnak a munkaeröpiacról, nehezen tudják a távmunkát is hatékonyan végezni, mert elszoknak a szabályoktól, irányítástól. Ide sorolhatjuk azokat a kisgyermekes anyákat is, akik gyes-en, gyeden vannak, időszakosan kikerülnek a munkából a gyer- 
meknevelés érdekében. Nagyon fontos, hogy a munkáltató aktív kapcsolatot tartson fenn a munkavállalójával, ne hagyja, hogy kirekesztődjön a munkaközösségből, hanem folyamatosan támogassa, a programokra meghívja, lehetôséget adjon a céges intraneten való tájékozódásra. Egyre több cégnek nagyon komoly programja van erre, például ilyen a gyes-menedzsment. A cég kezdetben atipikus formában alkalmazhatja a kisgyermekes anyukát, akár részmunkaidőben vagy távmunkában, aztán a gyermek növekedésével teljes munkaidőssé válhat a foglalkoztatása. Sok nő nem szívesen marad a távmunkában, mert az sok esetben elszigetelődést jelent, hanem inkább visszamegy a „valós” munkakörnyezetbe.

3. csoport: A harmadik csoportba tartoznak a karrierorientált nők, akik inkább saját, egyéni karrierigényüket helyezik előtérbe és a család háttérbe szorul. Gyermekvállalás után általában a karrierorientált nő hamar visszamegy dolgozni, a gyereket pedig neveli a bölcsőde, a nagyszülők vagy a bébiszitter. Az ilyen munkavállaló nagyon értékes a munkaadó számára, hiszen a szakmai fejlődésért, a magasabb pozícióért, esetleg a nagyobb (anyagi) elismerésért bármit megtesz. Az anya munkavállalásával kapcsolatos aggodalmak a Bowly-féle kötődéselméletre vezethetők vissza. Eszerint a kötődés és a gyermek későbbi egészséges lelki fejlödése élete első évében alakul ki, amikor a gyereknek fokozott szüksége van az anyjára (Nagy, 2013). Néhány tanulmány bizonyította, hogy az egy éves kor előtt bölcsődébe járó gyerekek nagyobb arányban lesznek magatartászavarosak (Bass et al., 2007). Külföldi példák alapján sem feltétlenül helytálló ez a megállapítás, ahol az anyák nem rendelnek minden tevékenységet a gyermeknevelés alá (szemben a magyarországi anyák egy részével), nem lesznek magatartászavarosak a gyerekeik. Az anyák munkába állási kockázatát vizsgálta Blaskó (2010), szerinte a hároméves kor előtti anyai munkavállalás önmagában nem okoz kárt a gyereknek, amennyiben elérhető és jó minőségü gyermekintézmények állnak rendelkezésre, a család és munkavégzés összeegyeztetését segítő társadalmi környezet, valamint, hogy az anya zökkenőmentesen léphessen vissza a munka világába. Azaz ő sem mondja, hogy az anyák a gyermek 3 éves koráig maradjanak otthon. Gyakori a vezető pozíciót betöltő nők esetében, hogy egy (vagy több) gyermeket vállalnak, és magas beosztást akarnak és tudnak elérni, ezért fontos, hogy a cég ne csak kecsegtessen, hanem adjon valós fejlődést, legyen tudatos, munkavállalóra orientált karriermenedzsmentje és támogassa a női munkavállalót anyai mivoltában is.

4. csoport: A negyedik típus a maximalista, aki az élet minden területén helyt akarállni: tökéletes feleség és mintaanya, kiváló munkaerő, akár vezető vagy vállalkozó és aktív közéleti ember is. Ezzel a saját egészségét és energiatartalékait emészti fel, de nem mond nemet sehol sem, így a munkahelyen sem. Ezért ha feladata van, azt megcsinálja, és ha kell, átszervezi a magánéletét, erre a csoportra mindig számíthat a munkaadó. Berényi és Deutsch (2017) tanulmányában kiemeli a növekvő számú női vezetőkre vonatkozó kihívásokat és a CSR-hoz való viszonyt. Kezd „kitermelődni” a negyedik csoportból egy olyan szegmens, miszerint a „kettős teher” vállalásából a magas vezető beosztásban lévő nők azokat a feladatokat, amelyek nem közvetlenül a gyermekneveléssel és az érzelmi motivációval kapcsolatosak, kezdik „megvásárolni”. A bejárónő elvégzi az otthoni munkát, akár mos és takarít is, így az otthon töltött időt a női vezető „,csak” a családjával való foglalkozással tölti. Öket hívhatjuk ,szabadidőt vásárlóknak". E nőknek fontos a kiszámíthatóság, az önmegvalósításon túl az anyagi biztonság és a megbecsülés is.

5. csoport: Az ötödik csoportba sorolhatók az egyensúlyozók, akik helyt akarnak állni mind a családban, mind a munkahelyen, de a munka világában csak kisebb felelösséggel járó, alacsonyabb beosztást vállalnak el, amit még el tudnak látni a családi kötelezettségek mellett is. Tehát ők nem törekednek magas beosztásra, fontos számukra, hogy „,időben” tudjanak végezni és odaérjenek az óvodazárásáig a gyerekért. Ezért nekik rugalmas, tervezhető munka kell, vagy kötetlen munkaidő, ahol maga osztja be az idejét, vagy kötött és túlóramentes munkahely, ahonnan alkalmanként el lehet jönni, ha pl. a gyereknek fellépése van.

\section{Összefoglalás}

A szakirodalom, a saját fókuszcsoportos vizsgálat és annak továbbgondolása alapján összefoglalásként felsoroljuk a kisgyermekes nők elhelyezkedési esélyeit gátló tényezőket. A foglalkoztatottságban mutatkozó különbségek elsősorban a nők munkahelyi és családi kötelezettségeinek összeegyeztetésével kapcsolatos nehézségekre vezethetők vissza. Ezek a következők: (1) A tradicionális szemlélet: nálunk van szinte egész Európában legerősebben jelen az a tradicionális szemlélet, amely szerint a nő helye nem a munkaeröpiacon, hanem a családi tüzhely mellett van. Ezen azok a realitások sem változtatnak, hogy jelentős a gyermekét egyedül nevelő nők aránya, hogy elsősorban a diplomás nők, de az alacsonyabb végzettségüek többsége sem szeretne otthon ragadni háztartásbeliként, illetve a magyar háztartások nagy részében elengedhetetlen a két kereset, így kényszer, hogy a nő is dolgozzon. (2) A munka világa nem alkalmazkodik a nők igényeihez: megoldatlan, illetve kevés a gyermekintézmények nyitva tartásához illeszkedő munkabeosztás. (3) Nehézkes a gyermekfelügyelet: a gyermekellátó intézmények nyitva tartása nem alkalmazkodik a női munkavállalók igényeihez, a munkarendekhez. (4) Többletköltséget jelent a kisgyermekes női munkavállaló: egyértelműen többletköltséget jelent a munkaadónak egy férfi vagy egy gyermektelen női alkalmazotthoz képest, hiszen a kiadások a fiatal nők gyermekvállalásához kötődnek, egy részük konkrétan a munkaadó által fizetendő tételek, más részük a női munkavállaló munkából való kieséséből adódó gyermekek utáni szabadság, helyettesítési és egyéb költségek. (5) „Macerás” munkavállalók: sok esetben a gyes-en lévő nők védelme, elbocsátásuk tilalma az, amiért a munkaadók kerülik a szülöképes korú fiatal nők alkalmazását, vagy a kisgyermekesek többletszabadsága, illetve nem rugalmassága (nem tud túlórázni, nem tud több munkarendet vállalni stb.) az ok, hogy nem veszik fel őket. (6) Sztereotípiák a kisgyerekes anyákkal kapcsolatban: állandóan beteg a gyerekük, nem elég rugalmasak, nem terhelhetőek, nem a 
munkájuk a legfontosabb az életükben, alkalmazkodniuk kell az óvodai és iskolai szünethez, három évig mindenképpen otthon maradnak, a gyes alatt beszükülnek, tudásuk elavul.

A szakirodalmakban leírt okok és magyarázatok szerint, a statisztikai adatok alapján és a fókuszcsoporton elhangzottak tükrében egyértelmüen megállapíthatjuk, hogy léteznek a hazai munkaerőpiacon a kisgyermekes nőkkel kapcsolatos sztereotípiák, melyek szerint „macerás" munkavállalók, azaz létezik a sztereotípián alapuló diszkrimináció1. Mindenképpen szükség van egy „,finomhangolásra" a kisgyermekes nők elhelyezkedésének előmozdítása érdekében. Jól kimutatható ellentmondások látszódnak a kisgyermekes nők és a HR/társadalom által megfogalmazott sztereotípiák között, ezért elengedhetetlen, hogy a két fél minél inkább megismerje a másik igényeit, jellemzőit és lehetőségeit. Fontos a szemléletformálás a munkaerőpiac mindkét szereplője kapcsán: a munkaadói oldalon annak érdekében, hogy a kisgyermekes nőket ne hátrányos helyzetű munkavállalónak, hanem potenciális munkaforrásnak tekintsék, a munkavállalói oldalon pedig azt kell sugallni, hogy tudatosan, önbizalommal, és ön-érdekérvényesítően kell a gyermekvállalást követően a munkaeröpiacra visszatérni.

Úgy véljük, hogy tanulmányunk a menedzsmenttudományok számára hasznos lehet, ugyanis a fókuszcsoportos vizsgálatba bevont HR-szakemberek menedzseri pozíciót töltenek be, továbbá a menedzsmenttudományok is foglalkoznak a hatékony emberierőforrás-gazdálkodással és az emberi tőke hasznosításával, amelynek fontos szegmense a kisgyermekes női munkavállalói csoport.

\section{Jegyzet}

${ }^{1}$ Az Egyenlő Bánásmód Hatóság honlapján számtalan jogeset olvasható a sztereotípián alakuló diszkriminációval kapcsolatban: http://www. egyenlobanasmod.hu/article/index/jogesetek

\section{Felhasznált irodalom}

Aranyi, E. (2001): Tendenciák a család és a munka összeegyeztetésére az Európai Unióban és Magyarországon. EU Working Papers, 4:(3), p. 60-89.

Asztalos-Morell, I. (1997): A nemek közötti egyenlőtlenségek az államszocializmus korszakában. Tézisek a feminista megközelítéshez. Szociológiai Szemle, 7:(3), p. 33-66.

Bálint M. - Köllő J. (2008): A gyermeknevelési támogatások munkaerő-piaci hatásai. Esély, 19:(1), p. 3-27.

Bass L. - Darvas Á. - Szomor É. (2007): Gyermeknevelési ok és gyerekintézmények. Mi a jó a gyerekeknek, mit szeretnének a szülők? htt p://www.gyerekesely. hu/component/option,com docman/task,doc details/ gid,215/Itemid,3

Beck-Gernsheim, E. (1976): Der geschlechtsspezifische Arbeitsmarkt: Zur Ideologie und Realität von Frauenberufen. Frankfurt am Main. Idézi: Belinszki, E. (1997): A munka nemesít? Elméleti magyarázatok a nők munkaerő-piai helyzetéről, Szociológiai Szemle, 7: (1), p. 133-155.
Berényi, L. - Deutsch, N. (2017): Gender Differences in Attitudes to Corporate Social Responsibility Among Hungarian Business Students. WSEAS Transaction on Business and Economic (14), p. 298-310.

Blaskó, Zs. (2010): Meddig maradjon ott hon az anya? - A gyermekfejlődés szempontjai. Esély, 21:(3), p. 89-116.

Bukodi, E. - Róbert, P. (1999): A nők munkaerő-piaci részvétele és a gyermekvállalás. Statisztikai Szemle, 77:(4), p. 201-224.

Fodor, É. - Vicsek, L. (2006): A different type of gender gap: How women and men experience poverty. East European Politics and Societies, 20:(1), p. 14-39.

Frey, M. (1996): A nők helyzete a munkahelyen és a háztartásban. In: Munkácsy Ferencné (szerk.): Foglalkoztatás, jövedelmi viszonyok, munkakörülmények. Budapest: Struktúra-Munkaügy Kiadó

Frey, M. (2001): Egyensúlyt teremteni a fizetett munka és a családi élet között. Demográfia, 44:(3-4), p. 280-304.

Frey, M. (2001): Nők és férfiak a munkaeröpiacon. In: Nagy Ildikó - Pongrácz Tiborné - Tóth István György (szerk): Szerepváltozások: Jelentés a nők és a férfiak helyzetéről, 2001. Budapest: Tárki

Garcia-Moran, E. M. (2010): Child Care Costs, Female Labor Force Participation and Public Policy. http://www. unavarra.es/digitalAssets/141/141105_100000Paper_ Eva_Garcia-Moran.pdf (letöltés ideje: 2017.08.08.)

Gardiner, J. (1975): Women's Domestic Labour. New Left Review, 89:(1-2), p. 47-58.

Kispéter, E. (2012): Producing Women Mothers: Maternalist Labor Control in a Hungarian Factory. Doktori értekezés. Budapest: CEU

Koltai, J. - Szalka, É. (2013): A vállalkozói hajlandóság vizsgálata a nöi hallgatók körében Magyarországon. Vezetéstudomány 44:(7-8), p. 71-97.

Köllö, J. - Nagy, Gy. (1995): Bérek a munkanélküliség előtt és után. Közgazdasági Szemle, 62:(4), p. 325-357.

Koncz, K. (1993): Nők a rendszerváltásban. Társadalmi Szemle, 48:(12), p. 24-37.

Koncz, K. (1996): Nők a vezetésben: létezik-e női vezetési stílus? Munkaügyi Szemle, 40:(7-8), p. 30-37.

Koncz, K. (1999): Nők a munkaerőpiacon a rendszerváltást követően. Munkaügyi Szemle, 43:(1), p. 22-27.

Koncz, K. (2008): Nők a munkaerőpiacon. Budapest: Közgazdasági és Jogi Könyvkiadó

Koncz, K. (2011): A munkaerőpiac nemek szerinti szegregációjának jellemzői, mechanizmusa és következményei. Közgazdasági Szemle, 58:(1), p. 74-94.

Koncz, K. (2016): A női karriertípusok és jellemzőik. Opus et Educatio, 3:(1), p. 30-39.

Krizsán, A. - Betlen, A.-Zentai, V. (2009): Partszélről a fösodorba: gender mainstreaming kézikönyv. Budapest: Clone Design Kft.

Lakatos, J. (2001): Visszatérés a munkaerőpiacra a gyermekgondozási idő után. Statisztikai Szemle, 79:(1) p. 56-63.

Lipták, K. - Matiscsákné Lizák, M. (2016): A magyarországi munkaerőpiac női vetülete. Gradus, 3:(1), p. 422427. 
Matiscsákné Lizák, M. (2006): Nők a munkaerőpiacon és a vezetésben (A női vezetők munkaerő-piaci pozícióját befolyásoló egyéni tényezők vizsgálata). Ph.D-értekezés. Kézirat. Miskolc: Miskolci Egyetem

Matiscsákné Lizák, M. (2016): A magyar női vezetők munkaerő-piaci jellemzőinek bemutatása. 6. Vezetéstudományi Konferencia „Menedzsment kihívások Taylor után 105 évvel" Konferencia, Szeged

Nagy, Á. (2013): Az anyai munkavállalás és a gyermekfejlődés összefüggései. Kapocs, 12:(2), p.14-23.

Nagy, B. (1997): Karrier női módra. In: Tóth István- Lévai Katalin (szerk.): Szerepváltozások: Jelentés a nők helyzetéről. Budapest: TÁRKI, Munkaügyi Minisztérium

Nagy, B. (1999): Munkahelyi előmenetel. In: Tóth István - Lévai Katalin (szerk.): Szerepváltozások: Jelentés a nők helyzetéről. Budapest: TÁRKI, Munkaügyi Minisztérium

Nagy, B. (2001): Női menedzserek. Budapest: Aula Kiadó

Nagy, B. (2005): Nők a vezetésben. In: Nagy Ildikó Pongrácz Tiborné - Tóth István György (szerk.): Szerepváltozások: Jelentés a nők és férfiak helyzetéről 2005. Budapest: TÁRKI, Ifjúsági, Családügyi, Szociális és Esélyegyenlőségi Minisztérium

Nagy, B. (2009): A munkavállalás és gyermekvállalás paradoxona - bevezető gondolatok. Szociológiai Szemle, 19:(3), p. 81-91.

Nagy, B. - Fodor, É. (2015): A gazdasági válság hatásai a férfiak és a nők munkaerő-piaci helyzetére Kelet-Közép-Európában. Szociológiai Szemle, 25:(3), p. 2-22.

Nagy, B. - Primecz, H. (2010): Nők és férfiak a szervezetben: kísérlet a mítoszok eloszlatására. Vezetéstudomány, 41:(1), p. 2-17.

Ostner, I. (1990): Das Konzept des Weiblichen Arbeitsvermögens. In: Arbeitspapiere aus dem Arbeitskreis Sozialwissenschaftliche Arbeitsmarktforschung, 22-39.o.

Primecz, H. - Kiss, Cs. - Toarnitzky, A. - Csillag, S. - Szilas, R. F. - Bácsi, K. - Milassin, A . (2014): Magyarországi „munkavállaló-barát” (employee friendly) szervezetek: Valóság vagy utópia: Avagy mit tanulhatunk tőlük? Vezetéstudomány, 45:(10), p. 2-16.

Scharle, Á. (2007): The Effect of Welfare Provisions on Female Labour Supply in Central and

Eastern Europe. Journal of Comparative Policy Analysis: Research and Practice, 9:(2) p. 157-174.

Szücs, I. (2005): A kisgyermekes nők belépési és visszatérési esélyei a munkaerőpiacra a család- és foglalkoztatáspolitikai eszközök viszonyrendszerében. Kutatási beszámoló. Echo Survey Szociológiai Kutatóintézet

Tóth, O. (1995): Hogyan egyeztethetö össze a női munka a családi szerepekkel? Info-Társadalomtudomány, 32:(5), p. 33-37.

Vajda, R. (2014): Munkaerőpiac, foglalkoztatás, vállalkozónők. A nők teljes értékű munkavállalásának akadályairól és esélyeiről. In: A nőtlen évek ára. Budapest: Magyar Női Érdekérvényesítő Szövetség, p. 99-151.

Vicsek, L. (2006): Fókuszcsoport. Budapest: Osiris Kiadó

Vicsek, L. (2017): Online fókuszcsoportok alkalmazása lehetőségek, korlátok és tanácsok a hatékonyság növelésére. Vezetéstudomány, 48:(4), p. 36-45.
Zoltayné Paprika, Z. - Nagy, V. (2013): A kreativitás megítélése a munkaerőpiacon. Vezetéstudomány, 44:(6), p. $2-13$.

\section{1. melléklet}

Az 5 fő kisgyermekes anya ismérvei:

1. alany: 28 éves, gyermek életkora: 2 év, felsőfokú végzettségü, GYES-en van, férjezett,

2. alany: 34 éves, gyermekek életkora: 10 és 14 év, középfokú végzettségü, alkalmazott, elvált,

3. alany: 32 éves, gyermek életkora: 8 év, felsőfokú végzettségü, vállalkozó, férjezett,

4. alany: 44 éves, gyermekek életkora: 11, 14 és 17 év, felsőfokú végzettségü, alkalmazott, elvált,

5. alany: 26 éves, gyermekek életkora: 4 és 6 éves, 8 általános, alkalmazott, férjezett.

A HR-s szakemberek ismérvei:

1. alany: 47éves, saját munkaerö-közvetítő és -kölcsönző céggel rendelkezik, 2 saját gyermeke van (18, 22 évesek), elvált, felsőfokú végzettségü,

2. alany: 32 éves, egy multi munkaközvetítő cégnél HR Recruiter/Toborzó, nincs gyermeke, hajadon, felsőfokú végzettségű,

3. 24 éves, egy multicégnél HR-asszisztens, nincs gyermeke, hajadon, középfokú végzettségü,

4. alany: 36 éves, egy önkormányzati cégnél HR-vezető, 1 gyermeke 8 éves, férjezett, felsőfokú végzettségü.

A két kutató ismérvei:

1. kutató: 32 éves, gyermektelen, hajadon, középvezetö, alkalmazott, felsőfokú végzettségü,

2. kutató: 50 éves, 3 gyermekes (16, 19, 24 évesek), férjezett, alkalmazott, felsőfokú végzettségű.

\section{2. melléklet}

A fókuszcsoportos beszélgetés félig strukturált kérdéslista alapján történt, az elöre megfogalmazott kérdések (interjúvázlat) az alábbiak voltak:

1. Mit gondolnak a résztvevők a nők munkaerő-piaci helyzetéről?

2. Mik azok a tényezők, amik befolyásolják a nők, különösen a kisgyermekes nök elhelyezkedését?

3. Melyek a kisgyermekes nők föbb jellemzői, vannak-e sztereotípiák velük kapcsolatban?

4. Hogyan lehet a munkát és a magánéletet összeegyeztetni a munkavállaló és a munkaadó szemszögéből egyaránt?

5. Milyen félelmeik vannak a kisgyermekes nőknek a munkába állást illetően?

6. Milyen akadályokat látnak a munkavállalók és a munkaadók a kisgyermekes anyák elhelyezkedését illetően?

7. Milyen a család- és nőbarát munkaerőpiac és a munkaadó?

8. Miért nem terjednek hazánkban az atipikus foglalkoztatási formák, elterjesztésükhöz mire van szükség? 